\title{
Shattered Dreams, Exploited Childhood, Tormented Sexuality and Inescapable Caste and Class in Arundhati's the God of Small Things
}

\author{
Shama Bee, Mohd. Jamshed \\ Research Scholar (Ph.D), Department of English, Aligarh Muslim University, UP
}

\begin{abstract}
Present Paper explores the issues, like caste, class, power, sexuality, and the position of women in The God of Small Things. Arundahti Roy as a social and political activist focuses on the contemporary and the current burning issues of India such as Indian politics, problem of untouchability, marginalization of the lower caste people, and sexual exploitation of the women of lower classes as well as the subjugation of women in general, brutality of the police, exploitation and oppression of the powerless by the powerful in post-colonial India. Roy also raises voice against the patriarchal and male oriented Indian society that always oppresses women sexuality, not allowing them to express their sexual liberty. Aтти is the worst victim of this patriarchal domination and rigid caste system who has to lose her life after her transgressive act of having the love affair and physical relation with an untouchable Pravan, Velutha. Roy also highlights the hierarchal power structure of Indian society which is based on caste system that generates a kind of binary oppositions: touchable/ untouchable, oppressor/oppressed, and Syrian/Paravan.
\end{abstract}

Keywords: Race, Caste, Class, Power, Sexuality and Women

\section{INTRODUCTION}

Arundahti Roy as a social and political activist focuses on the contemporary and the current burning issues of India such as Indian politics, problem of untouchability, marginalization of the lower caste people, and sexual exploitation of the women of lower classes as well as the subjugation of women in general, brutality of the police, exploitation and oppression of the powerless by the powerful in postcolonial India.

The God of Small Things as a postcolonial novel represents many modes of resistance and protest against the marginalization of the Indian culture by its own natives such as by Baby Kochamma, Chacko and Pappachi who are great anglophiles, believing in the superiority of Western ideas, culture, language and etiquettes. These people are Indian in blood and colour but Western in their attitude who undermine their own culture and people as Baby kochamma comments on the pilgrim's bhajan, "These Hindus... They have no sense of privacy" (86).

Roy criticizes the Indians, especially Chacko, Pappachi and Baby Kochamma, for believing in the Western superiority that is based on race and colour. Margaret Kochamma and Sophie Mol are welcomed everywhere, everybody makes them realize that they are special creatures having racial superiority to everyone in Ayemenem house. The English child Sophie Mol gets love, affection and care from all while the twins are neglected by the whole family even by the maid Kochu Maria. Hypocrisy and racial discrimination of Indian society is noticeable as Ammu being a divorcee is ignored, unwanted, unwelcomed and humiliated everywhere while Margaret Kochamma inspite of being separated from Chacko for the sake of a better future with another man is still welcomed, valued, respected and loved by everyone, even by Chacko himself, just because she is a white woman.

Roy's major concern in the novel is to raise voice against the cruel and obstinate Indian caste system that is accountable for "the Death in Custody of a technically innocent man" (314). Roy also highlights the hierarchal power structure of Indian society which is based on caste system that generates a kind of binary oppositions: touchable/untouchable, oppressor/oppressed, and Syrian/ Paravan. The Upper or middle class and caste people are seen to have a colonial mentality intended to subjugate the lower sections of the society. 
They believe that the untouchables are born to serve the upper caste people. Vellya Paapen and his son Velutha served the Ipe Family for generations. Vellya Paapen always remained obedient and ready to serve his 'masters'. Velutha in Chacko's factory is very skilled worker who can operate the technical machine he always works more than the other 'touchable' workers of the factory but is paid less than them. Even in post-colonial India, these Paravans, the lowest of the untouchables, are still colonized not by the White colonial master but by their own people belonging to upper castes like Chacko and Mammachi who have authority over them. The Pravans of Kerala are deprived of any social life and dignity being treated as an outcaste by the upper caste people. Political power structure that appears in the novel is like "Big Man the laltain, Small Man the mombatti" (88) with Chacko, Pillai Mammachi and Baby Kochamma being represented as 'Big Man' who have control, power and authority over Velutha, Ammu and Rahel and Estha, the powerless 'Small Man'. Ammu and her twins are also socially deprived inspite of belonging to the upper caste as they are treated like 'outcastes' in the Ayemenem family. Most of the time Estha and Rahel are humiliated by Baby Kochamma for living at their maternal grandfather's house and for being the children of a divorced woman who does not have any position in the Indian society .

Roy also raises voice against the patriarchal and male oriented Indian society that always oppresses women sexuality, not allowing them to express their sexual liberty. Ammu is the worst victim of this patriarchal domination and rigid caste system who has to lose her life after her transgressive act of having the love affair and physical relation with an untouchable Pravan, Velutha. As a 'woman' of upper caste, this is a sexual as well as social transgression on her part. Mammachi is also the victim of patriarchal Indian society. She is the silent sufferer of patriarchal domination: dominated, humiliated and beaten by her husband. After Pappachi's death she was dominated by her own son Chacko, who does not allow her to possess any legal right in her own factory.

Roy's The God of Small Things unveils the oppressive and exploitative nature of the power structures of Indian society, where the powerful take advantage of the powerless whenever they get a chance, as Estha's sexual molestation by the Lemon-Orange Drink man in the Abhilash Talkies is an example of it. This dangerous and traumatic experience of sexual molestation by Estha at the age of seven makes him terrorized and fearful as the narrator says: "Estha sat up and watched. His stomach heaved. He had a greenway, thick-watery, lumpy, seaweedy, floating, bottomless and bottomful feeling." (107). this traumatic consequence of sexual molestation that he carries from childhood to adulthood stretched a kind of insecurity within him. He is not able to believe anybody in the whole world not even Rahel, who knows him since before the life begins, because they were twins.

Rahel comes to her childhood home (the Ayemenem house) to reunite with her brother, in order to rediscover their pains, their haunted childhood experiences, their deserted adulthood, and their destroyed lives. This deep intimacy between the twins results in their incestuous sexual encounter, a thing not acceptable anyhow by the society. This worse transgression may be the outcome of the fact that no one in the whole world can understand them as they understand each other. As the narrator says "Perhaps Ammu, Estha and she were the worst transgressors. But it wasn't just them. It was the others too. They all broke the rules. They all crossed into forbidden territory, they all tampered with the laws that lay down who should be loved and how much."(31).

Like her non-fiction writings, Roy's The God of Small Things is also seemed an articulation of the sufferings of the marginalized and underprivileged people. She advocates the rights of the untouchables, the Paravans, the most oppressed and subaltern. She poses the question: can the Paravans have any right to raise voice against their marginalization, humiliation and discrimination based on the caste? Velutha's death through inhuman beatings by the police is an answer that they cannot have any right to be protected against the domination of upper caste people resulting in injustices perpetrated upon them.

The God of Small Things is centered on various postcolonial issues such as Eurocentrism, hybridity, mimicry, marginalization of culture, racial discrimination, passion for white skin and English language. Roy seems to be doing a critique of the domination of American capitalism, economical imperialism, neo-colonialism, and globalization and its impact on developing countries like India and its culture. Roy also focuses on Communism in Kerala and criticizes it for being used as a tool to consolidate the vote bank of the weaker sections of the society. K.N.M. Pillai and other leaders of the communist party use it for their own vested interests. Velutha becomes the victim of caste prejudices of the upper caste women Baby Kochamma and Mammachi, politics of communist party leader Pillai 
Shattered Dreams, Exploited Childhood, Tormented Sexuality and Inescapable Caste and Class in Arundhati's the God of Small Things

and brutality of Inspector Mathew. Roy's The God of Small Things is a social document that portrays social, political and economic turmoil of post-colonial India.

\section{REFERENCES}

[1] Mukesh, Sunanda."The Agony of Discrimination in Arundhati Roy's The God of Small Things." New Perspectives on Indian English Writings. Ed. Agrawal, Malti. New Delhi: Atlantic, 2007.187-197. Print.

[2] Nazari, Fahimeh. "Revisiting Colonial Legacy in Arundhati Roy's The God of Small Things". Diss. Journal of Education and Social Research, 3.1 (2013): 207. Print.

[3] Roy, Arundhati. The God of Small Things. New Delhi: Penguin, 2002. Print.

[4] Swain, S.P. "Erotic Pornography and Sexuality: A Study of the God of Small Things" Arundhati Roy the Novelist Extraordinary. Ed. R.K.Dhawan. New Delhi: Prestige, 2012. Print

\section{AUTHORS' BIOGRAPHY}

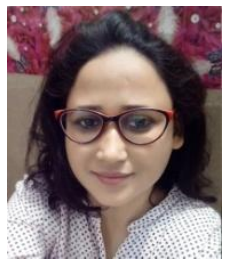

Shama Bee, Academic Qualification: M A (English) UGC NET (English), M.Phil (English)

Research Topic: A Postcolonial Reading of Arundhati Roy's The God of Small Things

Currently Pursuing PhD. from AMU, Aligarh

Research Topic: Patriarchy and Female Identity in the Select Novels of Tehmina Durrani and Tahmima Anam

have published various research papers

Area of Interest: Post-colonial Literature, Writings by Muslim Women Writers, Feminism Dalit Literature and Islamic Feminism

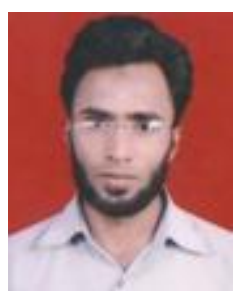

Mohd. Jamshed, M A (English), UGC NET (English) RSET (English)

Currently Pursuing PhD. from AMU, Aligarh

PHD Research Topic: Exploration of relationship in the Fictional world of Nayanatara Shagal's Select Novels

Have published various research papers.

My areas of interest: Contemporary fiction, Social and Political issues and Contemporary Issues. 